\title{
Differential pharmacology and clinical utility of sonidegib in advanced basal cell carcinoma
}

This article was published in the following Dove Press journal:

OncoTargets and Therapy

24 January 2017

Number of times this article has been viewed

\section{Mohd Wahid \\ Arshad Jawed \\ Sajad Ahmad Dar \\ Raju K Mandal \\ Shafiul Haque}

Research and Scientific Studies Unit, College of Nursing and Allied Health Sciences, Jazan University, Jazan,

Kingdom of Saudi Arabia
Correspondence: Shafiul Haque Research and Scientific Studies Unit, College of Nursing and Allied Health Sciences, Jazan University, Jazan 45I42, Kingdom of Saudi Arabia Tel/fax+966 I7 3174383

Email shafiul.haque@hotmail.com

\begin{abstract}
Patients suffering from advanced basal cell carcinoma (BCC) have very limited treatment options. Sonidegib selectively inhibits the growth of Hedgehog pathway-dependent tumors and can treat locally advanced BCC patients who are not candidates for surgery or radiation therapy. The BOLT clinical trials were conducted to evaluate the efficacy/ potency of sonidegib in the treatment of advanced BCC or metastatic BCC. The patients were randomized in 1:2 ratios to receive 200 or $800 \mathrm{mg}$ oral sonidegib daily, stratified by disease, histological subtype and geographical region. The primary efficacy analyses showed that 18 patients in the $200 \mathrm{mg}$ group and 35 patients in the $800 \mathrm{mg}$ group show an objective response (Central Review Committee) that corresponds to $43 \%$ (95\% confidence interval [CI]: 28-59) and 38\% (95\% CI: 28-48) in their respective categories. Disease control was found in $93 \%$ (39 patients) and 80\% (74 patients) of the patients administered 200 and $800 \mathrm{mg}$ sonidegib, respectively. The adverse events were assessed by the Central Review Committee as well as the investigator review team as per the guidelines of National Cancer Institute Common Terminology Criteria for Adverse Events version 4.03. The most frequently found adverse events reported in BOLT trials were muscle spasms, alopecia, dysgeusia (taste disturbance), nausea, elevated blood creatine kinase and fatigue. Comparatively, the patients administered $200 \mathrm{mg}$ sonidegib showed fewer adverse events than those in the $800 \mathrm{mg}$ sonidegib category. Thus, the benefit of using the $200 \mathrm{mg}$ dose of sonidegib outweighs the associated risks and it can be inferred that it would be judicious to choose doses of lesser strength.
\end{abstract}

Keywords: locally advanced basal cell carcinoma, metastatic basal cell carcinoma, central review, investigator review, BOLT clinical trials, objective response, complete response, partial response, disease control, event-free probability

\section{Introduction}

The history of oncology treatment has been associated with pessimism. The outcome of treatment becomes more uncertain for advanced basal cell carcinomas (BCCs). A majority of the BCCs are simple, but they pose a colossal challenge on reaching an advanced/metastatic stage. ${ }^{1}$ It is the most common malignancy responsible for human skin cancer, accounting for almost $80 \%$ cases. $^{2,3}$ Sonidegib (Odomzo ${ }^{\circledR}$, Novartis International AG, Basel, Switzerland) appeared as a ray of hope for advanced BCC-affected patients because of a satisfactory benefit-risk profile and the shortage of treatments available for this disease. ${ }^{4}$ Sonidegib is an oral Smoothened (SMO) antagonist, which acts as a Hedgehog pathway inhibitor. It is indicated for the treatment of adults with locally advanced BCC (laBCC) not suitable for surgery or radiation therapy or adults with recurrent laBCC following surgery or radiation therapy. ${ }^{4}$ 


\section{Treatment management of advanced BCC}

The incidence of BCCs is increasing by leaps and bounds across nations, particularly in the United States. Thus, scientists working all over the world have focused their attention on finding a successful treatment for advanced BCCs. ${ }^{5}$ The aim of the $\mathrm{BCC}$ treatment is to remove the tumor without much alteration in the function or physical appearance of the patient's affected area. The features that make advanced BCCs difficult to treat are large tumor size, location, extent and invasiveness of the disease. ${ }^{6}$ Different treatment options for advanced BCCs, such as electrodesiccation, curettage, cryosurgery, photodynamic therapy or topical agents, did not get the expected success. If there exists the possibility of surgery without deformity or loss of function to the patient for the treatment of advanced BCC, it is considered one of the best options. ${ }^{7}$

Radiation therapy has also been used for a long time to treat advanced BCCs and various other tumors. It utilizes high-energy rays, eg, X-rays, and particles, such as photons, electrons or protons, to kill tumor cells. This treatment is particularly useful when the tumor size is very large or on areas where surgical removal is difficult. It is also useful for patients who cannot withstand surgery due to other health reasons such as diabetes, old age, etc. ${ }^{8}$

The new category of drugs surfacing currently comprises oral agents that act as Hedgehog pathway inhibitors and that are very beneficial for the treatment of advanced BCC. The first-in-class drug in this category was vismodegib (Erivedge; Genentech, Inc., South San Francisco, CA, USA), made by Genentech, which received US Food and Drug Administra(FDA) approval and European marketing authorization the year 2012 and 2013, respectively. ${ }^{9}$ A new drug making waves these days, named sonidegib, has also been added in this category.

\section{Challenges faced by Hedgehog pathway inhibitors}

The failure of cancer drugs to treat diseases after showing their credentials is becoming common nowadays. The drugs are not losing their strength because of any alteration in their structure or way of functioning. The reason is mainly the drug resistance that develops due to change in the drug target. ${ }^{10}$ Drug resistance influences the treatment of various cancers such as blood cancer and solid tumors that include non-Hodgkin lymphoma, breast cancer, lung cancer and BCCs. The drugs such as vismodegib and sonidegib are also not left untouched by the problem of drug resistance. ${ }^{11}$
Vismodegib is affected by both primary and secondary resistances. The reason for primary resistance includes the mutation in SMO at position $497(\mathrm{G} \rightarrow \mathrm{W})$ in patients, whereby tumors started to grow after 2 months of randomization with vismodegib. The second type of resistance developing in the case of vismodegib use was due to a nonsense mutation in PTCH1 after following 11 months' continuous treatment. The mutation in SMO was found to be at position $473(\mathrm{D} \rightarrow \mathrm{Y})$.

The mutation that affects the treatment of advanced BCC by sonidegib is located at position 477 in SMO. This mutation at position 477 results in a change in amino acid from aspartic acid to glycine $(D \rightarrow G)$. This change leads to reduced sensitivity to Hedgehog pathway inhibitors and affects drug-target binding. The mentioned change is an acquired resistance that annuls the susceptibility of the advanced BCC patients to sonidegib treatment. ${ }^{12}$ It is a potential hurdle to durable response in the clinics. Alternate approaches of combining the different Hedgehog pathway inhibitors together to overcome 1 or more resistance can provide extra strength to treatment regimens for advanced BCC.

\section{Vismodegib}

Vismodegib inhibits the Hedgehog pathway by attaching itself to SMO (a transmembrane protein involved in Hedgehog pathway signal transduction). It is a first-in-class SMO inhibitor approved by the US FDA in January 2012. It was filed under priority review for the treatment of metastatic or advanced BCC, which appears again after surgery or is incurable with surgery or radiation due to significant deformity or loss of function. ${ }^{13}$

\section{Pharmacokinetics}

Vismodegib is a very permeable compound with absolute bioavailability of $31.8 \%$. The absorption rate of vismodegib reaches a saturable point after a single dose of 270 or $540 \mathrm{mg} .{ }^{13}$

The distribution of vismodegib varies from 16.4 to $26.6 \mathrm{~L}$. The plasma protein binding of vismodegib is more than $99 \%$ and it binds to both human serum albumin and alpha-1-acid glycoprotein (saturable limit).

Vismodegib as a whole and its metabolites, are eliminated mainly by the hepatic route. Thus, $82 \%$ of the total administered dose is recovered in the feces, whereas $4.4 \%$ is recovered in urine. The $t_{1 / 2}$ (half-life) of vismodegib as calculated was 4 days after continuous administration of once-daily dose and 12 days after a single dose. 


\section{Efficacy of vismodegib}

Vismodegib has shown good results in an international, 2-cohort phase 2 trial in patients suffering from metastatic BCC or laBCC, conducted in the year 2012. These trials were conducted to test the efficacy of the drug. ${ }^{1}$ The number of patients suffering from laBCC was 71 out of 104 enrolled for the study. Eight patients were dropped from the study as they did not fulfill the criteria, such as histologically confirmed laBCC, Eastern Cooperative Oncology Group (ECOG) performance status of $0-2$, a skin lesion of not less than $10 \mathrm{~mm}$ (for locally advanced patients) and nonfeasibility of surgical or radiotherapeutic treatment. The remaining 63 patients suffering from laBCC were assessed by independent investigators. Objective response was shown by 27 patients, which corresponds to almost $43 \%$ (95\% confidence interval [CI]: $31-56 ; P<0.001$ ), with $21 \%$ patients (ie, 13 patients) showing complete response. Thus, vismodegib shows good efficacy in the treatment of laBCC.

\section{Sonidegib}

Sonidegib, with the trade name Odomzo ${ }^{\circledR}$, is a Hedgehog pathway inhibitor approved by the US FDA in the year 2015 for the treatment of patients suffering from laBCC that has recurred following surgery or radiation therapy or for those on whom surgery/radiation therapy cannot be performed. It binds Smo (a transmembrane protein), which results in the inhibition of Hedgehog signal transduction. It helps in reducing the growth of cancer cells. The recommended dose of sonidegib is $200 \mathrm{mg}$ taken orally once a day on an empty stomach. ${ }^{14}$ A majority of cancer treatments produce mild-to-moderate adverse events that can be managed with dosage modification, concomitant medications, adequate hydration, etc.

\section{Pharmacokinetics}

Less than $10 \%$ is absorbed in the patient's body from the total administered dose. After the administration of a single oral dose (from 100 to 3,000 mg) of sonidegib under fasting conditions to patients suffering from cancer, it attains the median time to peak concentration $\left(T_{\max }\right)$ in approximately 2-4 hours, whereas after repeated dosing, $T_{\max }$ is reached after $2-13$ hours. ${ }^{15,16}$ Sonidegib is mainly metabolized by the liver through the action of cytochrome P450 3A (CYP3A). ${ }^{13-15,17}$ The estimated $t_{1 / 2}$ of sonidegib as calculated using population pharmacokinetics (PKs) is approximately 28 days and it is mainly excreted out through the hepatic route. From the total absorbed dose of sonidegib, $70 \%$ is removed in the feces, whereas $30 \%$ is eliminated along with urine. ${ }^{16,18}$

\section{Efficacy of sonidegib}

The potential of any drug is measured by assessing the maximum response achievable and capacity for sufficient therapeutic effect that benefits the patient/ultimate user. The therapeutic competence of any drug is proved first in clinical trials, followed by its launch in the market.

The evaluation of sonidegib's efficacy was done in a clinical trial named BOLT. ${ }^{19}$ It was a multicenter, randomized, double-blind phase 2 study conducted in 58 centers across 12 countries.

\section{Patient selection method}

Almost 269 patients were screened for inclusion in the clinical trials. The eligible patients had to fulfill the conditions such as age of the patients (18 years or more), histologically confirmed laBCC (disease not manageable by radiotherapy or curative surgery), or metastatic BCC for which the available treatments were not working. The patients had WHO status from 0 to $2 .{ }^{20}$ All the patients had given their written consent before their enrollment in the clinical trials. The number of patients not enrolled in the study was 39 . Out of these 39 patients, 30 did not qualify in the eligibility criteria, whereas 6 patients retracted by themselves and 3 patients were excluded by the physician. The remaining 230 patients were randomized and administered 2 doses of sonidegib daily in separate groups of 200 and $800 \mathrm{mg}$, until they had disease progression, incidence of intolerable toxicity, start of another anticancer treatment or withdrawal of consent. The number of patients assigned for 200 and $800 \mathrm{mg}$ doses were 79 and 151, respectively. The patients included in the primary efficacy analysis were 55 for the $200 \mathrm{mg}$ dosage group, whereas for the $800 \mathrm{mg}$ dosage group, the number was 116 . Both 200 and $800 \mathrm{mg}$ dosage groups included the patients for the safety analysis as well. All the patients in the $200 \mathrm{mg}$ intent-to-treat population (ie, 79) were used for the safety analysis, whereas for the $800 \mathrm{mg}$ category, the patients used for the safety analysis were 150 out of 151 .

The primary efficacy analysis of sonidegib for the treatment of laBCC was divided into 2 categories, namely, administration of 200 and $800 \mathrm{mg}$ sonidegib (Table 1). The first category of 42 patients was administered $200 \mathrm{mg}$ of sonidegib daily, whereas the second category of 93 patients was infused with $800 \mathrm{mg}$ of sonidegib once daily. The various end points analyzed were objective response, disease control, duration of tumor response, progression-free survival, etc. The study was assumed to be successful if $30 \%$ or more of the patients achieved objective response. The Central Review Committee, 
Table I Comparison of response rates of patients administered 200 and $800 \mathrm{mg}$ sonidegib to evaluate its activity against laBCC in the primary efficacy and intent-to-treat populations

\begin{tabular}{|c|c|c|c|c|}
\hline \multicolumn{5}{|c|}{$\begin{array}{l}\text { Activity of sonidegib for the treatment of locally advanced basal cell carcinoma in the primary efficacy and intent-to-treat } \\
\text { populations }\end{array}$} \\
\hline \multirow[t]{2}{*}{ Parameter studied } & \multicolumn{2}{|c|}{$\begin{array}{l}\text { Primary efficacy population } \\
\text { (laBCC) }\end{array}$} & \multicolumn{2}{|c|}{ Intent-to-treat population (laBCC) } \\
\hline & $\begin{array}{l}\text { Sonidegib } \\
(200 \mathrm{mg}) ; \mathrm{n}=42\end{array}$ & $\begin{array}{l}\text { Sonidegib } \\
(800 \mathrm{mg}) ; \mathrm{n}=93\end{array}$ & $\begin{array}{l}\text { Sonidegib } \\
(200 \mathrm{mg}) ; \mathrm{n}=66\end{array}$ & $\begin{array}{l}\text { Sonidegib } \\
\text { (800 mg); } n=128\end{array}$ \\
\hline \multicolumn{5}{|l|}{ Central review } \\
\hline Proportion of patients (objective response) & $18(43 \%)$ & 35 (38\%) & $31(47 \%)$ & $45(35 \%)$ \\
\hline$[95 \% \mathrm{Cl}]$ & [28-59] & [28-48] & {$[35-60]$} & {$[27-44]$} \\
\hline Complete response & $2(5 \%)$ & 0 & $2(3 \%)$ & 0 \\
\hline Partial response & $16(38 \%)$ & $35(38 \%)$ & $29(44 \%)$ & 45 (35\%) \\
\hline Disease control & 39 (93\%) & $74(80 \%)$ & $60(91 \%)$ & $100(78 \%)$ \\
\hline Time to tumor response, months $(95 \% \mathrm{Cl})$ & $3.9(2.1-4.0)$ & $3.7(2.0-3.8)$ & $3.9(3.6-4.2)$ & $3.7(2.6-3.8)$ \\
\hline \multicolumn{5}{|l|}{ Duration of tumor response } \\
\hline Number of events & 3 & I & 4 & 3 \\
\hline \multicolumn{5}{|l|}{$[95 \% \mathrm{Cl}]$} \\
\hline \multicolumn{5}{|l|}{ Progression-free survival } \\
\hline Number of events & 5 & 8 & 7 & 10 \\
\hline Duration (months) & NR & NR & NR & $N R$ \\
\hline $\begin{array}{l}\text { Event-free probability (after } 12 \text { months of randomization) } \\
{[95 \% \mathrm{Cl}]}\end{array}$ & $84 \%$ [59-94] & $83 \%[67-91]$ & $84 \%$ [65-93] & $86 \%[73-93]$ \\
\hline \multicolumn{5}{|l|}{ Investigator review } \\
\hline Proportion of patients (objective response) & $28(67 \%)$ & $54(58 \%)$ & $43(65 \%)$ & $73(57 \%)$ \\
\hline$[95 \% \mathrm{Cl}]$ & {$[50-80]$} & [48-68] & [52-76] & {$[48-66]$} \\
\hline Complete response & $3(7 \%)$ & $12(13 \%)$ & $5(8 \%)$ & $15(12 \%)$ \\
\hline Partial response & $25(60 \%)$ & $42(45 \%)$ & $38(58 \%)$ & $58(45 \%)$ \\
\hline Disease control & 39 (93\%) & $82(88 \%)$ & $59(89 \%)$ & $110(86 \%)$ \\
\hline Time to tumor response, months $(95 \% \mathrm{Cl})$ & $1.9(1.2-3.7)$ & $1.8(1.1-2.0)$ & $1.9(1.8-3.7)$ & $1.9(1.2-2.0)$ \\
\hline \multicolumn{5}{|l|}{ Duration of tumor response } \\
\hline Number of events & 5 & 6 & 10 & 10 \\
\hline \multicolumn{4}{|l|}{$[95 \% \mathrm{Cl}]$} & $77 \%[59-88]$ \\
\hline \multicolumn{5}{|l|}{ Progression-free survival } \\
\hline Number of events & 9 & 13 & 15 & 17 \\
\hline Duration (months) & 22 & NR & 17 & NR \\
\hline $\begin{array}{l}\text { Event-free probability (after } 12 \text { months of randomization) } \\
{[95 \% \mathrm{Cl}]}\end{array}$ & $74 \%[50-87]$ & $70 \%[52-82]$ & $69 \%[5|-8|]$ & $71 \%[57-882]$ \\
\hline
\end{tabular}

Abbreviations: $\mathrm{Cl}$, confidence interval; laBCC, locally advanced basal cell carcinoma; NR, not recorded.

after analyzing the BOLT trials, found that $43 \%$ patients in the $200 \mathrm{mg}$ category and $38 \%$ in the $800 \mathrm{mg}$ category showed objective response. Complete response was shown by $5 \%$ patients administered $200 \mathrm{mg}$ sonidegib, whereas no patients administered $800 \mathrm{mg}$ drug showed complete response. Partial response was shown by approximately $38 \%$ in both the categories of patients, while disease control was shown by $93 \%$ and $80 \%$ patients in their respective groups (ie, 200 and $800 \mathrm{mg}$ ). The investigator review committee had also analyzed the results of the BOLT clinical trials. Objective response was found to be $67 \%$ and $58 \%$ in the patients in 200 and $800 \mathrm{mg}$ groups, respectively. Patients in both the groups, ie, $7 \%$ patients in the $200 \mathrm{mg}$ group and $13 \%$ patients in the $800 \mathrm{mg}$ group, showed complete response. The partial responses were $60 \%$ and $45 \%$, respectively, in the mentioned categories. The disease control was also excellent, as analyzed by the investigator review committee, shown by around $93 \%$ and $88 \%$ patients in the 200 and $800 \mathrm{mg}$ categories, respectively. The results shown by both the analytical groups (ie, central review and investigator review) in the intent-to-treat population were also comparable with those of the primary efficacy patient population.

\section{Safety}

The adverse events were assessed by the central review as well as by the investigator review teams. ${ }^{19}$ All the $\mathrm{Z}$ events 
experienced by the patients following the administration of 200 and $800 \mathrm{mg}$ doses of sonidegib were reviewed as per the guidelines of the National Cancer Institute Common Terminology Criteria for Adverse Events version 4.03. ${ }^{21}$ The adverse events were evaluated from Day 1 , when the first dose of sonidegib was administered, until the last dose, which was administered on Day 30. Generally, the most common adverse events reported in BOLT trials were muscle spasms, alopecia, dysgeusia (taste disturbance), nausea, elevated blood creatine kinase and fatigue. ${ }^{19}$ The patient group administered $800 \mathrm{mg}$ sonidegib showed adverse events more frequently compared with the patients infused with $200 \mathrm{mg}$ of sonidegib. The most frequently reported grade 3-4 adverse events, such as elevated kinase levels, were shown by many patients, followed by increased lipase levels. If we consider both 200 and $800 \mathrm{mg}$ sonidegib doses that were administered to both types of patients, those suffering from $\mathrm{laBCC}$ and metastatic BCC, the most common adverse event that led to the discontinuation of the treatment by the patients was muscle spasm ( $3 / 79$ patients in the $200 \mathrm{mg}$ sonidegib group and $13 / 150$ patients in the $800 \mathrm{mg}$ sonidegib group).

\section{Opinion}

The Hedgehog inhibitors have proved themselves as promising alternatives for patients with advanced BCC who are not amenable to radiotherapy or surgery. ${ }^{22}$ The current review is based mainly on BOLT clinical trials conducted across 12 countries all over the world in around 58 centers. It was a double-blind, randomized, phase 2 study to test the efficacy of sonidegib in 2 tolerable doses (ie, 200 and $800 \mathrm{mg}$ ) for the treatment of laBCC as well as metastatic BCC. The focus here is on laBCC, which affects many patients across the globe. The patients were analyzed and were assigned to $\mathrm{laBCC}$ and metastatic $\mathrm{BCC}$ groups as required. The laBCC patients (42 in number) were administered $200 \mathrm{mg}$ sonidegib daily, whereas 93 patients were administered $800 \mathrm{mg}$ sonidegib daily. The percentage of patients who showed objective response was $43 \%$ and $38 \%$ in their respective categories, which appears to be comparatively good, although complete response was shown by proportionately fewer patients in the $200 \mathrm{mg}$ category and none in the $800 \mathrm{mg}$ category. However, the disease control ratio was quite impressive, ie, $93 \%$ and $80 \%$.

The safety profiles of both 200 and $800 \mathrm{mg}$ sonidegib dosage groups were assessed by following the guidelines of the National Cancer Institute Common Terminology Criteria for Adverse Events version 4.03. ${ }^{21}$ The frequently found adverse events in the patients were muscle spasms, alopecia, dysgeusia (taste disturbance), nausea, elevated blood creatine kinase and fatigue, which sometimes have led many patients to discontinue their treatment. These adverse reactions were more common in the patients administered $800 \mathrm{mg}$ sonidegib. Drugs such as tizanidine (muscle relaxant) can be recommended to increase the tolerability of patients who show muscle toxicity after the administration of sonidegib. Furthermore, it was found in the study that muscle toxicity and dysgeusia were prominent between the first and third weeks. Hence, drug scheduling and reduced drug strength are recommended. ${ }^{23}$

The emergence or rebound of resistance in the case of vismodegib has already terrified other Hedgehog inhibitors as well. ${ }^{24}$ Patients who were resistant to vismodegib for the treatment of advanced BCCs have continued the legacy for sonidegib. ${ }^{25}$ So, alternate approaches of combining the drugs after assessing the mechanism of resistance developed in the laBCC patients are recommended, which would bypass the hindrance posed in the way of treating this category of patients. The combination of B-cell lymphoma-2 (BCL-2) inhibitors and chemotherapy has already shown promising results in overcoming acquired resistance. ${ }^{26,27}$ The combination of BCL-2 inhibitors and chemotherapy sensitizes the resistant patients for cancer treatment. These BCL-2 inhibitors, if combined with sonidegib, may show better results and avoid advanced $\mathrm{BCC}$ recurrence due to acquired resistance.

\section{Acknowledgment}

Authors are grateful to Jazan University, Kingdom of Saudi Arabia, for providing the necessary facilities for this study.

\section{Disclosure}

The authors report no conflicts of interest in this work.

\section{References}

1. Sekulic A, Migden MR, Oro AE, et al. Efficacy and safety of vismodegib in advanced basal-cell carcinoma. $N$ Engl J Med. 2012; 366(23):2171-2179.

2. Caro I, Low J. The role of the hedgehog signaling pathway in the development of basal cell carcinoma and opportunities for treatment. Clin Cancer Res. 2010;16(13):3335-3339.

3. Rubin AL, Chen EH, Ratner D. Basal-cell carcinoma. $N$ Engl J Med. 2005;353(21):2262-2269.

4. Burness CB, Scott LJ. Sonidegib: a review in locally advanced basal cell carcinoma. Target Oncol. 2016;11(2):239-246.

5. Mohan SV, Chang ALS. Advanced basal cell carcinoma: epidemiology and therapeutic innovations. Curr Dermatol Rep. 2014;3(1):40-45.

6. National Comprehensive Cancer Network. NCCN Clinical Practice Guidelines in Oncology: Basal Cell Skin Cancer. NCCN. Available from: www.nccn.org/professionals/physician_gls/pdf/nmsc.pdf. Version 2, 2016. Accessed December 21, 2016. 
7. Puig S, Berrocal A. Management of high-risk and advanced basal cell carcinoma. Clin Transl Oncol. 2015;17(7):497-503.

8. Avril MF, Auperin A, Margulis A, et al. Basal cell carcinoma of the face: surgery or radiotherapy? Results of a randomized study. $\mathrm{Br} \mathrm{J}$ Cancer. 1997;76(1):100-106.

9. Dlugosz A, Agrawal S, Kirkpatrick P. Vismodegib. Nat Rev Drug Disco. 2012;11:437-438.

10. Holohan C, Schaeybroeck SV, Longley DB, Johnston PG. Cancer drug resistance: an evolving paradigm. Nat Rev Cancer. 2013;13: 714-726.

11. Wahid M, Jawed A, Mandal RK, et al. Vismodegib, itraconazole and sonidegib as hedgehog pathway inhibitors and their relative competencies in the treatment of basal cell carcinomas. Crit Rev Oncol Hematol. 2016;98:235-241.

12. Dijkgraaf GJ, Alicke B, Weinmann L, et al. Small molecule inhibition of GDC-0449 refractory smoothened mutants and downstream mechanisms of drug resistance. Cancer Res. 2011;71(2):435-444.

13. Erivedge ${ }^{\circledR}$ (Vismodegib) [package insert]. US Prescribing Information; 2012.

14. Kish T, Corry L. Sonidegib (Odomzo) for the systemic treatment of adults with recurrent, locally advanced basal cell skin cancer. Pharm Ther. 2016;41(5):322-325.

15. Odomzo ${ }^{\circledR}$ (Sonidegib) [package insert]. US Prescribing Information; 2015.

16. Zollinger M, Lozac'h F, Hurh E, et al. Absorption, distribution, metabolism, and excretion (ADME) of ${ }^{14} \mathrm{C}$-sonidegib (LDE225) in healthy volunteers. Cancer Chemother Pharmacol. 2014;74(1):63-75.

17. European Medicines Agency. Summary of product characteristics (Odomzo). London: European Medicines Agency; 2015.

18. Odomzo ${ }^{\circledR}$ (Sonidegib) [package insert]. US Prescribing Information; 2015. (U.S. Food and Drug Administration, 10903 New Hampshire Avenue, Silver Spring, MD 20993).
19. Migden MR, Guminski A, Gutzmer R, et al. Treatment with two different doses of sonidegib in patients with locally advanced or metastatic basal cell carcinoma (BOLT): a multicentre, randomised, double-blind phase 2 trial. Lancet Oncol. 2015;16(6):716-728.

20. WHO. WHO Handbook for Reporting Results for Cancer Treatment. Geneva: World Health Organization; 1979.

21. US Department of Health and Human Services. National Cancer Institute. Common Terminology Criteria for Adverse Events (CTCAE) Version 4.03; 2010. Available from: https://evs.nci.nih.gov/ftp1/CTCAE/ CTCAE_4.03_2010-06-14_QuickReference_5×7.pdf. Accessed November 14, 2016.

22. Chen L, Silapunt S, Migden MR. Sonidegib for the treatment of advanced basal cell carcinoma: a comprehensive review of sonidegib and the BOLT trial with 12-month update. Future Oncol. 2016;12(18):2095-2105.

23. Dreier J, Dummer R, Felderer L, Nägeli M, Gobbi S, Kunstfeld R. Emerging drugs and combination strategies for basal cell carcinoma. Expert Opin Emerg Drugs. 2014;19(3):353-365.

24. Pricl S, Cortelazzi B, Col VD, et al. Smoothened (SMO) receptor mutations dictate resistance to vismodegib in basal cell carcinoma. Mol Oncol. 2014;9(2):389-397.

25. Danial C, Sarin KY, Oro AE, Chang AL. An investigator-initiated open-label trial of sonidegib in advanced basal cell carcinoma patients resistant to vismodegib. Clin Cancer Res. 2016;22(6):1325-1329.

26. Ni Chonghaile T, Letai A. Mimicking the BH3 domain to kill cancer cells. Oncogene. 2008;27(suppl 1):S149-S157.

27. Oakes SR, Vaillant F, Lim E, et al. Sensitization of BCL-2 expressing breast tumors to chemotherapy by the BH3 mimetic ABT-737. Proc Natl Acad Sci U S A. 2012;109(8):2766-2771.
OncoTargets and Therapy

\section{Publish your work in this journal}

OncoTargets and Therapy is an international, peer-reviewed, open access journal focusing on the pathological basis of all cancers, potential targets for therapy and treatment protocols employed to improve the management of cancer patients. The journal also focuses on the impact of management programs and new therapeutic agents and protocols on

\section{Dovepress}

patient perspectives such as quality of life, adherence and satisfaction. The manuscript management system is completely online and includes a very quick and fair peer-review system, which is all easy to use. Visit http://www.dovepress.com/testimonials.php to read real quotes from published authors. 